\title{
Determinants of Non-Performing Loan in South Asia: The Role of Financial Crisis
}

\author{
Obaid Ur REHMAN ${ }^{*}$
}

Received: April 26, 2017

Revised: November 23, 2017

Accepted: December 3, 2017

\begin{abstract}
The purpose of the study is to recognize the factors influencing non-performing loan in banking system of South Asian region for the period of 1999-2015. Generalized method of moment (GMM) is used to grasp the hetero nature of data at variant countries and apply impulse response function for robustness of results. The study results reveals that NPL is influenced by both macroeconomic indicators and bankspecific variables (although the bank-specific variables found to be low explanatory power due to their time variant indulgence, which marginally surge the within explanatory impact of every group while diminishes the between influence in the fixed effect estimations). The analysis indicates that NPL response to macroeconomic determinants is more significant in the post crisis period than pre crisis period. The scenario is suggesting that the level of NPL adversely affecting the economic recovery system in South Asian region.
\end{abstract}

Keywords: Non performing loan, macro and microeconomic linkage, South Asia, GMM, financial stability

JEL Code Classification: B21, B22, E32, E44, E58, E51, G21

UDC: 336.717 .42 (5-13)

DOI: https://doi.org/10.17015/ejbe.2017.020.07.

Agriculture University, Peshawar, Pakistan. E-mail: obaidktk@hotmail.com 


\section{Introduction}

\subsection{Background of the study}

It is growingly documented that the augmented level of bank non-performing loans (NPL) results in diminishing the economic position of the country. Raising level of NPL in many of the South Asian region enforce great burden on banks financial position (esp. the bank lending operations). The current increase in NPL widely affects banks, corporate and retail sector. The marginal augmented movement of NPL is seen after the financial crisis of 2008. The upward trends in the NPL resulting increasing unemployment, depression in the financial market, slow down the credit worthiness of the borrower and irrational upward movement in the inflation rate. Other than the fore stated factors, NPL in various countries seems having high standard deviation, which means non-negligible of some bank specific factors.

Primarily the study aims to investigate the determinant of NPL in all South Asia domiciled countries (Afghanistan, Bangladesh, Bhutan, India, Malaysia, Maldives, Nepal, Pakistan and Sri Lanka) by looking both (bank and macroeconomic indicator) level over 1999 to 2015. Secondly the study analyzes the reaction of banks to real economy by a panel vector auto-regression (VAR) model by including five endogenous variables (NPL, inflation, unemployment, change in credit to GDP ratio and real GDP Growth) to check how current increase in NPL affecting the South Asian economic activity within the study period.

The results suggest that NPL is affected by both (bank and macroeconomic indicator) level factors. Among the macroeconomic determinants, the results suggest that higher unemployment rate, exchange rate depreciation (against the dollar) and higher inflation contribute to higher NPLs while higher South Asian area's GDP growth results in lower NPLs. Higher global risk aversion (VIX) was also found to increase NPLs. The impact of bank-specific factors is broadly in line with the literature: equity-to-asset ratio and return on equity (ROE) are negatively correlated with NPLs while excessive lending (measured by loan-to-asset ratio and the past growth rate of banks' lending) leads to higher NPLs. Although bank-level factors have a significant impact on NPLs, their overall explanatory power was found to be low.

The research elucidates the response of NPL towards economic growth. The aim of the research work is to investigate the sensitivity of NPL towards the major macroeconomic developmental indicators in all South Asian listed countries. More specifically, the study investigates all the financial listed banks in the South Asian continents which make a set of 195 cross sections over a time of 17 periods. The study employs more samples and lengthy time period to cop the hetero nature non-performing loan shocks.

To put light on every question, the study is arranged in sections as follows: SectionII elucidates a brief review over literature. Section-III exposes the data and sources 
of data, detail of all bank in the South Asian listed countries and variable explanation of the study. Section-IV sums up the suffix and prefix of the empirical outcomes and diagnostics of the data on hand. Section- $V$ concluded the empirical results and put the finishing remarks over future direction. In this section, the study is putting the recommendation for prospective challenges and policy implication.

\section{Literature Review}

\subsection{Determinants of NPL in South Asian Region}

The literature elucidates the NPL by two different ways. One school of thoughts focuses on macroeconomic indicators like external events while other group focuses on bank specific variables like bank advances, performance etc. The empirical literature however supports both of the school of thoughts in that sense.

\subsubsection{Bank Level Factors}

Williams (2004) postulates association between cost efficiency and loan quality among European savings banks for the period of 1990 to 1998. Podpiera and Weil (2008); Louzis et al., (2012), all they analyses the NPL determinants in the Greek banking sector, and finally upkeep this hypothesis. Berger and DeYoung (1997), analyses the relationship between NPLs, cost efficiency and capitalization in commercial banks of US from 1985 to 1994, and conclude a two-way causality between NPLs to cost efficiency. While they explained the causality from cost efficiency to NPLs as "bad luck," determined primarily by weakening in macroeconomic situations, they explained this causality from cost efficiency to NPLs through the hypothesis of "bad management." In particular, this hypothesis contends that low cost efficiency is a sign of weak management performs, therefore suggesting that as a result of poor loan underwriting, monitoring and control, NPLs are probable to surge.

Berger and DeYoung (1997) postulates a hypothesis about cost-conscious, which recommend a probable favorable causality between NPLs and optimized cost efficiency. Specifically, there work proposes that optimized cost efficiency imitate small resources to monitor the lending risk and ultimately resulting higher NPLs in future. Such hypothesis is congruent with Reinhart and Rogoff (2010) who analyses a 278 banks from 1995 to 2002 from nine transition countries.

Keeton and Morris (1987) identify the moral hazard hypothesis. Researcher point out low capital banks respond to moral hazard encouragements by boosting the riskiness of their loan-portfolio, which consequently resulting higher NPLs on average in future. Researcher contended that additional loss rates were protuberant among banks that had comparatively low capital ratio. Salas and Saurina (2002), and Berger and DeYoung (1997), also found the negative link between the equity-to-asset ratio and NPLs. 
Keeton and Morris (1987) postulates that those banks who take extra risk in the form of excessive lending resultantly facing higher losses in the form of NPLs. Their work was favored by Jimenez and Saurina (2005), and Salas and Saurina (2002).

\section{Table 1. Summary of recent literature}

\begin{tabular}{|c|c|c|c|c|c|}
\hline Ind. Var. & Reference & Expected Sign & Result & Model & Dep. Var. \\
\hline \multicolumn{6}{|c|}{ Bank Specific Variables } \\
\hline \multirow{2}{*}{ NPL $(-1)$} & Klein (2013) & + & + & GMM & NPL \\
\hline & Makri, (2013) & + & + & GMM & NPL \\
\hline \multirow{7}{*}{ RGDP } & Klein (2013) & $+/-$ & - & GMM & NPL \\
\hline & Makri, (2013) & - & - & GMM & NPL \\
\hline & Castro (2013) & $+/-$ & - & GMM & Credit Risk \\
\hline & Beck et al., (2015) & - & + & GMM & NPL \\
\hline & Chaibi and Ftiti (2015) & - & - & GMM & NPL \\
\hline & Erdinç and Gurov (2016) & - & - & GMM & NPL \\
\hline & Boudriga et al., (2009) & - & + & DPD & NPL \\
\hline \multirow{3}{*}{ Unemployment } & Klein (2013) & $+/-$ & + & GMM & NPL \\
\hline & Makri, (2013) & + & + & GMM & NPL \\
\hline & Chaibi and Ftiti (2015) & + & + & GMM & NPL \\
\hline \multirow{2}{*}{ ER } & Klein (2013) & $+/-$ & + & GMM & NPL \\
\hline & Chaibi and Ftiti (2015) & $+/-$ & + & GMM & NPL \\
\hline \multirow{5}{*}{ Inflation } & Klein (2013) & $+/-$ & + & GMM & NPL \\
\hline & Makri, (2013) & $+1-$ & - & GMM & NPL \\
\hline & Chaibi and Ftiti (2015) & $+/-$ & - & GMM & NPL \\
\hline & Erdinç and Gurov (2016) & - & - & GMM & NPL \\
\hline & Boudriga et al., (2009) & $+/-$ & + & DPD & NPL \\
\hline VIX & Klein (2013) & $+/-$ & + & GMM & NPL \\
\hline \multicolumn{6}{|c|}{ Macroeconomic variables } \\
\hline \multirow[t]{3}{*}{ LTA } & Klein (2013) & $+/-$ & + & GMM & NPL \\
\hline & Makri, (2013) & + & + & GMM & NPL \\
\hline & Beck et al., (2015) & + & + & GMM & NPL \\
\hline \multirow[t]{2}{*}{ ETA } & Klein (2013) & $+/-$ & - & GMM & NPL \\
\hline & Erdinç and Gurov (2016) & + & - & GMM & NPL \\
\hline \multirow[t]{3}{*}{ LG } & Klein (2013) & $+/-$ & + & GMM & NPL \\
\hline & Makri, (2013) & $+/-$ & + & GMM & NPL \\
\hline & Erdinç and Gurov (2016) & + & + & GMM & NPL \\
\hline \multirow[t]{4}{*}{ ROE } & Klein (2013) & $+/-$ & - & GMM & NPL \\
\hline & Makri, (2013) & - & - & GMM & NPL \\
\hline & Hasna Chaibi (2016) & - & - & $\begin{array}{c}\text { Ordered } \\
\text { probit }\end{array}$ & CRSKit \\
\hline & Chaibi and Ftiti (2015) & - & - & GMM & NPL \\
\hline
\end{tabular}

\subsubsection{Macroeconomic factors}

Literature postulates the rotating nature of NPL. The common definition is that greater RGDP growth tends to boost up the income which progress the capacity of debt provision for the debtor. On the other hand, when the RGDP is diminishing, the NPL level is likely to boost up. As the level of unemployment also increases, so 
the debtor faces many complications in repaying their debt (Rajan \& Dhal, 2003; Salas \& Suarina, 2002; Jimenez \& Saurina; 2005; Fofack, 2005)

Literature also contends some other profound macroeconomic variable which somehow affecting the bank performance comprising of inflation, interest rate and exchange rate. With this respect, Louzis, et al., (2012) postulates that interest rate trudges affect the service of repaying the debt, especially when interest rate is floating, depreciation in the domestic currency shows unfavorable correlation with bank performance, especially in countries majorly dealing in foreign currencies to unfreeze the debtor. However, the inflation shocks are vague. Inflation can diminish is real worth of outstanding loan which make the debt servicing convenient. Conversely when wages are sultry, it diminishes the debtor real income. Nkusu (2011) postulates that countries having floating loan rate, there more inflation lead to augmenting rates causing from the action of monetary policy to fight inflation. Literature also postulates that NPLs are affected by stock prices. It is generally seen that the general decrease in the stock price lead to high defaults which affects the wealth and ultimately the collections.

It is true that banking sector is still the only home for financial arbitrators in many regions (esp. South Asia). But due to globalization, the dynamic environment generate diverge nature of challenges for the manager to cop the control on financial operation. Meanwhile the stress about augmenting performance in a dynamic environment is persistently testing the lender guts of identifying the borrower worthiness to payback their loan. The scenario sometimes divulged as mishap in the shape of NPL which regresses contemptuous impact over the economic growth. In the meantime, the exogenous shocks also shudder the surface of economic growth in diversion.

The contributory factors to NPL are many, but NPL response to factors is the real question which is responding by the on hand paper. These factors indulge major economic indicators such as unemployment, inflation, gdp, exchange rate and VIX and also specific financial factors such as lending rate, loan growth rate and equity to asset ratio.

\section{Data and Methodology}

\subsection{Data Description}

The analysis covers all South Asian listed countries for the period of 1999-2015. NPL to total loan ratio was obtained from GFSR publications and from FSI (IMF's Financial Soundness Indicators) while CPI inflation, GDP growth and unemployment data is taken from the World Economic Outlook database. Private sector credit data is obtained from IFS (International Financial Statistics).

The study sample comprises a total of 213 banks whose market capitalization is $70 \%$ of the whole banking system in country $i$ at time $t$ from 1999 to 2015. It makes a total of 3621 observations. The study employs banks' balance sheet panel data as 
well as macroeconomic indicators datasets. All the commercial banks within the continent scope (whose data is available for the study period) are taken as population of the research work. Bank specific variables are equity to asset ratio, return on equity, loan to asset ratio and loan growth rate are noted from each bank annual report and financial highlights mentioned on their respective website. Three country specific variables (inflation, the change in exchange rate and the change in unemployment rate) and two global variables (specific continent zone GDP growth and global risk aversion captured by the implied volatility of the Standard and Poor's country's stock market index)

NPL value is taken annually which consists of total 213 sample observations, which are majorly clustered in the 0 to $10 \%$ subdivision as shown in the Table 2.

\section{Table 2. Number of banks in South Asian listed countries}

\begin{tabular}{clc}
\hline No. & South Asian Countries & Number of Banks \\
\hline 1 & Afghanistan & 8 \\
2 & Bangladesh & 38 \\
3 & Bhutan & 5 \\
4 & India & 53 \\
5 & Malaysia & 14 \\
6 & Maldives & 4 \\
7 & Nepal & 20 \\
8 & Pakistan & 46 \\
9 & Sri Lanka & 25 \\
Total & & 213 \\
\hline
\end{tabular}

The $\triangle N P L s$ is fairly disseminated around 0 , although with a comparatively lofty difference. On the other hand, NPLs knock down sharply in some countries within the South Asia such as India and Bangladesh and during 2008 to 2009 (the financial crisis period) while rapidly augmenting in Pakistan, Sri Lanka and Nepal. The correlations among the variables are mostly congruent with the economic theory: there is negative correlation between NPLs and GDP growth and bank specific earning variables.

Table 3. Variable Explanation

\begin{tabular}{cll}
\hline Symbol & \multicolumn{1}{c}{ Explanation } & \multicolumn{1}{c}{ Formula } \\
\hline NPL & Non-Performing Loan & Bank NPL to Total Loan \\
Unemp & Unemployment & Unemployment rate \\
Inf & Inflation & CPI (\%) \\
ER & Exchange Rate & Country Currency to US dollar \\
RGDP & Real Gross Domestic Product & Real GDP Growth rate \\
VIX & Global Risk Aversion & Implied volatility of stock index \\
ETA & Equity to Asset ratio & Total Equity/Total Asset \\
ROE & Return on Equity ratio & PAT/Total Equity \\
LTA & Loan to Asset Ratio & Total Loan/Total Asset \\
LG & Loan Growth & Lending at first difference \\
\hline
\end{tabular}


The positive correlation of NPL is found with unemployment, exchange rate and VIX which supporting the economic theory. Surprisingly inflation is conversely correlated with NPL.

The study applies Fisher-PP and Fisher-ADF tests to evaluate the integration level which allow data gaps and do not require a fair sample. For each panel, the study conducts individually a unit-root test. From these tests, $p$ values are combined to construct an overall test. Table 6 indicated that all the variables are stationary at level except ER which is stationary at first difference. So the unit root for $\mathrm{H}_{0}$ can rejected for all variable at confidence level of $95 \%$. The condition number for the study variables is 22.9332. A condition number greater than 50 is commonly regarded as indicating strong collinearity. It means all variables have no collinearity problem at level (Source: Gretl collinearity check test).

\subsection{Methodology}

To weigh up the degree and extent of analysis, the study applies panel VAR methodology which also intermingle the VAR traditional approach. The VAR traditional approach endogenously weigh up all variables, which examine panel data unobserved heterogeneity individually. This technique is advantageous due to not requiring earlier supposition regarding feedback between model's variables. The study take help from Love and Zicchino (2006) written program in making the study model:

$Y_{i, t}=r_{0}+\sum_{i=1}^{n} r_{s} Y_{i, t-s}+f_{i}+e_{i, t}$

$y_{i, t}=\left[\alpha y_{i t-1}+\beta B_{i, t-1}+\gamma C_{t}+\delta G_{t}+\epsilon_{i, t}\right]$

Where $n p l_{i, t}$ is the non performing-loan to total-loan ratio in the country $i$ at year $t$. The dependent variable is transformed into logit using excel function for the sake of symmetrical distribution. Logit transformation of $n p l_{i, t}$ guarantees the distribution interval over $[+\infty,-\infty]$, which means the scattering is proportioned. The study employ VAR model so $n p l_{i, t}$ is explaining by its lag $n p l_{i, t-1}$, bank-level variables are explained by $B_{i, t-1}$ country-specific variables $C_{t}$ global variables $G_{t}$. Country $i$ specific traits are considered fixed for the time $t$ which is denoted in the model by $f_{i}$. However, these specific traits which are considered fixed during the study, are correlated with regression due to dependent variable lags. So the study uses a forward mean differencing (Helmert procedure), which confiscate all forward future observations mean available for each country $i$ at time $t$ (Arellano \& Bover, 1995).

Impulse response function is used to measure the dynamic behavior of the model. Such function explains that one variable reaction in the system effect on uniqueness of another variable in the system by keeping constant all other shocks. The shocks in the VAR were statistically independent using Cholesky decomposition, which argues that variables come into view first in the 
chronologically ordering are considered more exogenous, while those appearing later in the ordering are considered more endogenous. In this pattern, study follows the supposition that NPLs (only with lag) will be affected by unemployment, GDP growth and inflation. Furthermore, economic activities which are mainly executed through credit are significantly affected by NPLs. Hence $n p /$ come out first in sorting, while $\Delta c r e d i t_{i, t}$, unp, $\Delta g d p_{i, t}$, and $\Delta c p i_{i, t}$ appear later respectively. Qualitatively, such consequences remain generally unmoved for unconventional sorting.

Generalize method of moments (GMM) develop by Arellano and Bover (1995) and Blundell and Bond (1998) is used where number of $t$ is small compare crosssectional observations $(\mathrm{T}<$ or $=\mathrm{N})$, otherwise asymptotic impression and biases may arise (Caselli et al., $2008 \quad$ ). The study uses two equations in a system GMM to reduce potential bias and impression associated with first-difference GMM estimator (Arellano \& Bover, 1995; Blundell \& Bond, 1998). Primarily Sargan/Hansen test for over-identifying restrictions which tests for overall validity of the instruments and the $\mathrm{H}_{0}$ is that all instruments as group are exogenous (therefore higher $p$-value is better). Secondly test examines the $\mathrm{H}_{0}$ that error term of the difference equation is not serially correlated particularly at the second order (AR2).

\section{Empirical Results}

\subsection{Descriptive Statistics}

The macroeconomic variables show high volatility across time and countries (Table 4). High level of NPL has been recorded in 1999 and 2010 for all countries in South Asia (Figure 1). For instance, the level of inflation recorded highly mostly in Pakistan, India, and Afghanistan in last stage, while negative inflation was recorded in Maldives in the beginning stage of the study period. ER also moved sharply in some countries like Pakistan, Sri Lanka, Bangladesh and Bhutan during the study period.

\section{Table 4. Descriptive Statistics}

\begin{tabular}{lccccccccc}
\hline Variables & Obs. & Mean & Median & Max. & Min. & S.D & Skewness & Kurtosis & Jarque-Bera \\
\hline NPL & 3315 & 0.0902 & 0.0744 & 0.4990 & 0.0000 & 0.0848 & 1.4740 & 5.8569 & $2327.915^{* * *}$ \\
Unemp & 3315 & 0.0481 & 0.0430 & 0.1440 & 0.0140 & 0.0192 & 1.3389 & 5.2090 & $1664.524^{* * *}$ \\
Inf & 3315 & 0.0681 & 0.0620 & 0.3566 & -0.068 & 0.0411 & 1.6333 & 10.001 & $8245.799^{* * *}$ \\
ER & 3315 & 1.7287 & 1.7867 & 2.1586 & 0.4857 & 0.3509 & -2.4614 & 8.7851 & $7970.102^{* * *}$ \\
RGDP & 3315 & 0.0664 & 0.0710 & 0.0905 & 0.0371 & 0.0170 & -0.4490 & 1.9626 & $260.0544^{* * *}$ \\
VIX & 3315 & 0.0213 & -0.058 & 3.0945 & -1.515 & 1.2060 & 0.7212 & 3.1819 & $292.0092^{* * *}$ \\
ETA & 3315 & 0.0765 & 0.0530 & 9.9547 & -0.195 & 0.2238 & 27.923 & 1162.08 & $1.86 E^{+08 * * *}$ \\
ROE & 3315 & 0.0678 & 0.0377 & 23.093 & -61.35 & 1.1840 & -39.521 & 2232.4 & $6.87 \mathrm{E}^{+08 * * *}$ \\
LTA & 3315 & 0.3321 & 0.3978 & 7.2219 & 0.0000 & 0.3490 & 4.7277 & 80.056 & $832502.9^{* * *}$ \\
LG & 3315 & 0.0925 & 0.0000 & 7.2226 & -8.542 & 0.5385 & -2.5440 & 83.632 & $901607.5^{* * *}$ \\
\hline
\end{tabular}


Determinants of Non-Performing Loan in South Asia: The Role of Financial Crisis

The microeconomic level variable also shows corrosion in the bank assets quality since the occurrence of financial crisis and evident in their respective balance sheets. NPL is highest as whole in South Asia in 1999 and 2010 (Figure 1) while sharply declining afterwards.

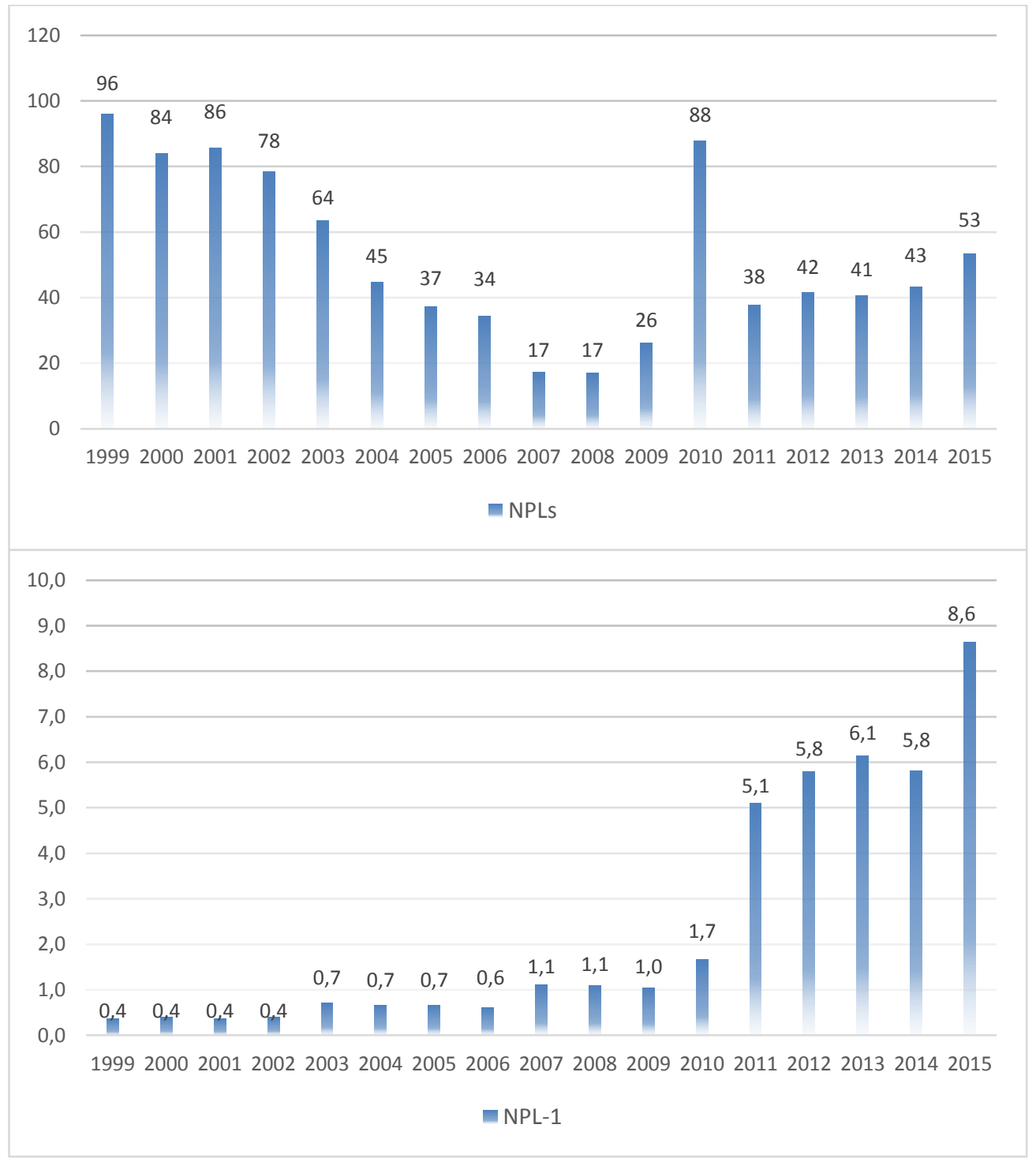

Figure 1. Distribution of the Level and $\triangle N P L s, 1999-2015$ 


\subsection{Correlation Statistics}

Strong negative correlation of NPL with the development indicator (e.g. RGDP) has been observed within all South Asian regions (Table 5). The positive impact of NPL seems in unemployment in all regions which resultantly devalue their domestic currency and tighten their financial position.

Table 5. Correlation statistics of NPL with explanatory variables of South Asian Countries

\begin{tabular}{ccccccccccc}
\hline & $\mathrm{NPL}(1)$ & Unemp(2) & $\operatorname{Inf}(3)$ & $\mathrm{ER}(4)$ & $\mathrm{RGDP}(5)$ & $\mathrm{VIX}(6)$ & $\mathrm{ETA}(7)$ & $\mathrm{ROE}(8)$ & $\mathrm{LTA}(9)$ & $\mathrm{LG}(10)$ \\
\hline 1 & 1 & 0.15987 & -0.2077 & 0.0001 & -0.2083 & 0.0221 & -0.0360 & -0.0218 & -0.2622 & -0.1147 \\
2 & 0.1598 & 1 & 0.0732 & 0.1238 & -0.0186 & -0.0096 & -0.0076 & -0.0230 & -0.1247 & -0.0477 \\
3 & -0.2077 & 0.07320 & 1 & 0.3836 & 0.0759 & 0.1872 & 0.0931 & -0.0094 & 0.1423 & 0.0557 \\
4 & 0.0019 & 0.12382 & 0.3836 & 1 & -0.0082 & -0.0277 & 0.0539 & -0.0215 & -0.0252 & 0.0349 \\
5 & -0.2083 & -0.01860 & 0.0759 & -0.0082 & 1 & -0.5691 & 0.0457 & 0.0013 & 0.1087 & 0.0045 \\
6 & 0.0221 & -0.00967 & 0.1872 & -0.0277 & -0.5691 & 1 & -0.0286 & 0.0018 & -0.0343 & -0.0361 \\
7 & -0.0360 & -0.00761 & 0.0931 & 0.0539 & 0.0457 & -0.0286 & 1 & 0.0016 & 0.2061 & 0.0533 \\
8 & -0.0218 & -0.02300 & -0.0094 & -0.0215 & 0.0013 & 0.0018 & 0.0016 & 1 & 0.0316 & 0.0037 \\
9 & -0.2622 & -0.12475 & 0.1423 & -0.0252 & 0.1087 & -0.0343 & 0.2061 & 0.0316 & 1 & 0.1478 \\
10 & -0.1147 & -0.04770 & 0.0557 & 0.0349 & 0.0045 & -0.0361 & 0.0533 & 0.0037 & 0.1478 & 1 \\
\hline
\end{tabular}

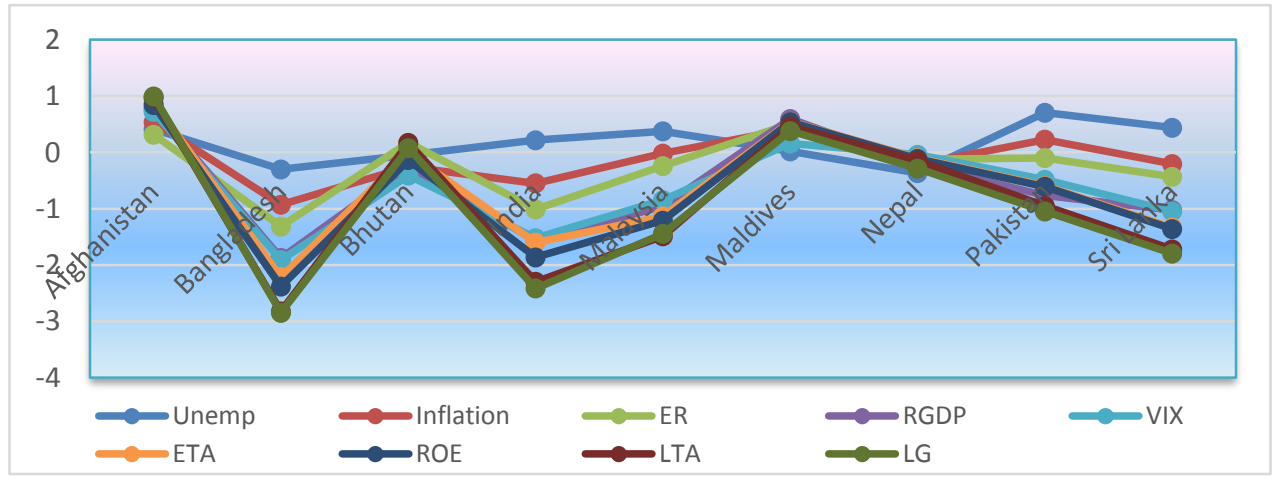

Figure 2. Correlational Statistics of NPL with other explanatory variables

\subsection{Diagnostic Tests}

\subsubsection{Unit Root testing}

The study diagnoses the panel unit root by using Fisher (ADF and PP) test as mentioned in Table 6. The unit root is tested at level (1) and at first difference. The hypotheses of unit root testing are:

$\mathrm{H}_{0}: \rho-1=0 \Rightarrow$ not stationary

$\mathrm{H}_{1}: \rho-1<0 \Rightarrow$ stationary 
The result exposes that all variables are stationary at level except for ER and at first difference. After this, the study run the panel co-integration model because the pre-condition of panel co-integration model is that the variable must contain unit root at level but when converted into first difference, then it will become stationary. Fisher (ADF and PP) test can fulfill the condition of panel co-integration model, so it can be considered as benchmark of the study

\section{Table 6. Unit Root Test}

\begin{tabular}{|c|c|c|c|c|c|}
\hline \multirow{3}{*}{ Variables } & \multicolumn{4}{|c|}{ Fisher Type } & \multirow{3}{*}{$\begin{array}{l}\text { Automatic lag } \\
\text { length selection } \\
\text { based on SIC: }\end{array}$} \\
\hline & \multicolumn{2}{|c|}{$\begin{array}{l}\text { Augmented Dickey Fuller } \\
\text { (ADF) }\end{array}$} & \multicolumn{2}{|c|}{ Phillips Perron (PP) } & \\
\hline & At Level & $\begin{array}{c}\text { At } 1^{\text {st }} \\
\text { Difference }\end{array}$ & At Level & $\begin{array}{c}\text { At } 1^{\text {st }} \\
\text { Difference }\end{array}$ & \\
\hline NPL_1 & $\begin{array}{l}624.850 \\
(0.0000)\end{array}$ & $\begin{array}{l}1080.13 \\
(0.0000)\end{array}$ & $\begin{array}{l}598.769 \\
(0.0000)\end{array}$ & $\begin{array}{l}1089.73 \\
(0.0000)\end{array}$ & 0 to 3 at level \\
\hline Unemp & $\begin{array}{l}495.758 \\
(0.0002)\end{array}$ & $\begin{array}{l}2142.61 \\
(0.0000)\end{array}$ & $\begin{array}{l}603.064 \\
(0.0000)\end{array}$ & $\begin{array}{l}2501.62 \\
(0.0000)\end{array}$ & 0 to 2 at level \\
\hline $\operatorname{lnf}$ & $\begin{array}{l}675.285 \\
(0.0000)\end{array}$ & $\begin{array}{l}2102.03 \\
(0.0000)\end{array}$ & $\begin{array}{l}659.990 \\
(0.0000)\end{array}$ & $\begin{array}{l}2835.32 \\
(0.0000)\end{array}$ & 0 to 1 at level \\
\hline ER & $\begin{array}{l}223.897 \\
(1.0000)\end{array}$ & $\begin{array}{l}1802.37 \\
(0.0000)\end{array}$ & $\begin{array}{l}317.317 \\
(0.9971)\end{array}$ & $\begin{array}{l}2060.15 \\
(0.0000)\end{array}$ & 0 at difference \\
\hline RGDP & $\begin{array}{l}1026.55 \\
(0.0000)\end{array}$ & $\begin{array}{l}2366.31 \\
(0.0000)\end{array}$ & $\begin{array}{l}1073.08 \\
(0.0000)\end{array}$ & $\begin{array}{l}4684.03 \\
(0.0000)\end{array}$ & 0 at level \\
\hline VIX & $\begin{array}{l}604.569 \\
(0.0000)\end{array}$ & $\begin{array}{l}1517.85 \\
(0.0000)\end{array}$ & $\begin{array}{l}665.523 \\
(0.0000)\end{array}$ & $\begin{array}{l}1655.07 \\
(0.0000)\end{array}$ & 0 at level \\
\hline ETA & $\begin{array}{l}686.040 \\
(0.0000)\end{array}$ & $\begin{array}{l}1745.75 \\
(0.0000)\end{array}$ & $\begin{array}{l}647.281 \\
(0.0000)\end{array}$ & $\begin{array}{l}1930.16 \\
(0.0000)\end{array}$ & 0 to 3 at level \\
\hline ROE & $\begin{array}{l}751.283 \\
(0.0000)\end{array}$ & $\begin{array}{l}1916.55 \\
(0.0000)\end{array}$ & $\begin{array}{l}1162.88 \\
(0.0000)\end{array}$ & $\begin{array}{l}2406.26 \\
(0.0000)\end{array}$ & 0 to 3 at level \\
\hline LTA & $\begin{array}{l}464.493 \\
(0.0000)\end{array}$ & $\begin{array}{l}1590.54 \\
(0.0000)\end{array}$ & $\begin{array}{l}410.829 \\
(0.0077)\end{array}$ & $\begin{array}{l}1653.72 \\
(0.0000)\end{array}$ & 0 to 3 at level \\
\hline LG & $\begin{array}{l}5117.62 \\
(0.0000)\end{array}$ & $\begin{array}{l}2248.96 \\
(0.0000)\end{array}$ & $\begin{array}{l}6211.90 \\
(0.0000)\end{array}$ & $\begin{array}{l}2796.54 \\
(0.0000)\end{array}$ & 0 to 3 at level \\
\hline
\end{tabular}

\subsubsection{Multicollinearity identifier}

Multicollinearity is a problem which makes it difficult to determine the separate effects of individual variables. The simplest diagnostic is to use the correlation coefficients (extreme collinearity being represented by a correlation coefficient of 1 ). Hair et al., (2006) recommend that a very small tolerance value ( 0.10 or below) indicate low collinearity or a large VIF value (10 or above) indicates high collinearity. The mean value of VIF test (Table 7) 1.23 postulate that all independent variable variances are centered on the regression line. It means that the variables do not contain multicollinearity problem.

\section{Table 7. Multicollinearity test}

\begin{tabular}{lcl}
\multirow{2}{*}{ Multicollinearity test } & Mean VIF value & Hypothesis \\
\cline { 2 - 3 } & 1.23 & $\mathrm{H}_{0}$ : No multicollinearity if Mean VIF $<10$ \\
\hline
\end{tabular}




\subsubsection{Heteroskedasticity tests}

The Gauss-Markov postulates that:

$Y_{i}=\alpha+\beta X_{i}+u_{i}$

$\mathrm{u}_{\mathrm{i}} \sim \mathrm{iid}\left(0, \sigma^{2}\right)$

Where $\sim i d\left(0, \sigma^{2}\right)$ means that error is independently and identically distributed with zero mean and $\sigma^{2}$ variance. The general hypothesis of heteroskedasticity is following:

$\mathrm{H}_{0}$ : Homoscedasticity, the variance of the residual is constant

$\mathrm{H}_{1}$ : Heteroskedasticity, the variance of the residual is unequal

The test finds that data contain the heteroscedasticity problem (Table 8). The problem is tackle by using the FGLS (Feasible Generalized Leas Square) test introduced by Kmenta (1986) and PCSE (Panel Corrected Standard Error) test by Parks (1967). PCSE and FGLS both can tackle the problem of heteroscedasticity, auto correlation and cross section dependence problems but if $\mathrm{N}>\mathrm{T}$, PCSE perform better than FGLS.

Table 8. Heteroskedasticity tests

\begin{tabular}{lll}
\hline Tests & Static & p-value \\
\hline Breusch-Pagan LM & 786.773319 & 0.0000 \\
Glesjer LM & 1897.689803 & 0.0000 \\
Harvey-Godfrey LM & 2925.150183 & 0.0000 \\
Park LM & 527.282627 & 0.0000 \\
White LM (no cross) & 575.837371 & 0.0000 \\
White LM (with cross) & 758.756837 & 0.0000 \\
\hline
\end{tabular}

\subsubsection{Autocorrelation}

It is the correlation of the variable having same value within the observation. Violation of the assumption is happening when $\operatorname{Cov}[\varepsilon i, \varepsilon j]=0$, where $\varepsilon i \neq \varepsilon j$. In the presence of autocorrelation, the function of $Y$ can be expressed as:

$Y=\beta_{0}+\beta_{1} X_{1}+\varepsilon_{t}$

Where $\varepsilon_{\mathrm{t}}=\beta_{1} \varepsilon_{\mathrm{t}-1}+\mu$

The autocorrelation problem is tested and verified by the Durbin Watson statistic value. The econometrics regarding the Durbin Watson statistic value is:

$D=\frac{\sum_{i=2}^{n}\left(e_{i}-e_{i-1}\right)^{2}}{\sum_{i=1}^{n} e_{i}^{2}}$

The possible range for $D$ value is $0 \leq D \leq 4$. $D$ should be close to 2 if $H 0$ is true. If $D<$ 2 ; it signals positive autocorrelation, $\mathrm{D}>2$ signal negative autocorrelation. The hypotheses for the test are given below:

$\mathrm{H}_{0}$ : Residuals are not correlated 
$\mathrm{H}_{1}$ : Autocorrelation is present

The test result exposes the $D$ value $=2.442493$, which means that data does not contain the autocorrelation problem.

\section{Table 9. Cointegration Test}

\begin{tabular}{lclc}
\hline Kao Residual & t-Statistic & Prob. & Automatic lag length selection based on AIC \\
\cline { 2 - 4 } Cointegration Test & -2.978494 & 0.0014 & 3 \\
\hline
\end{tabular}

Table 10. Serial Correlation LM Tests

\begin{tabular}{lccll}
\hline & Lags & LM-Stat & Prob & Hypothesis \\
\cline { 2 - 5 } VAR Residual Serial & 1 & 3668.550 & 0.0000 & \\
Correlation LM Tests & 2 & 3392.230 & 0.0000 & $\mathrm{H}_{0}$ : no serial correlation at lag order \\
& 3 & 1848.995 & 0.0000 & \\
\hline
\end{tabular}

Table 11. Feasible Generalized Least Square (FGLS)

Feasible Generalized Wald chi2(9) Prob. Correlation: common AR(1) coefficient for all panels $\begin{array}{llll}\text { Least Square (FGLS) } & 414.73 & 0.0000 & 0.7357\end{array}$

Table 12. Prais-Winsten regression

\begin{tabular}{|c|c|c|c|c|}
\hline \multirow{2}{*}{$\begin{array}{l}\text { Prais-Winsten regression, } \\
\text { correlated panels corrected } \\
\text { standard errors (PCSEs) }\end{array}$} & Wald chi2(9) & Prob. & R-squared & rho \\
\hline & 13.41 & 0.1448 & 0.1688 & 0.7356861 \\
\hline
\end{tabular}

\subsection{Robustness}

The level of NPL cannot be compared at variant regions due to different explanation at different places. So for robustness, the study applies alternative estimation that grasps the response of NPL to all other explanatory variables (Figure 3 and Figure 4).

\subsubsection{Response of NPL to shocks in macroeconomic variables}

The impulse response function confirms the NPL impact on different macroeconomic indicators. Other things keep constant, at 1 percent positive change in NPL results in increasing the unemployment and inflation by 0.38 and 3.15 respectively. Furthermore, if $R G D P$ is boost up by 1 , the NPL will goes down by 1.40 percent respectively.

\subsubsection{Response of NPL to shocks in bank-specific variables}

The bank specific variable exerts strong response toward NPL. Other things keep constant, at 1 percent change in NPL results in results in 21.89, 125.88, 25.04 and 40.30 percent change in ETA, ROE, $L T A$ and $L G$ respectively. All the variables (macro and micro) toward NPL are significant at $95 \%$ confidence level.

The response of microeconomic variables to $N P L$ is more than macroeconomic variables. It has also been noted that response of inflation and $E R$ to NPL is more than that of explained in the literature (Espinosa \& Prasad, 2010; Nkusu, 2011; IMF working paper, 2013). 

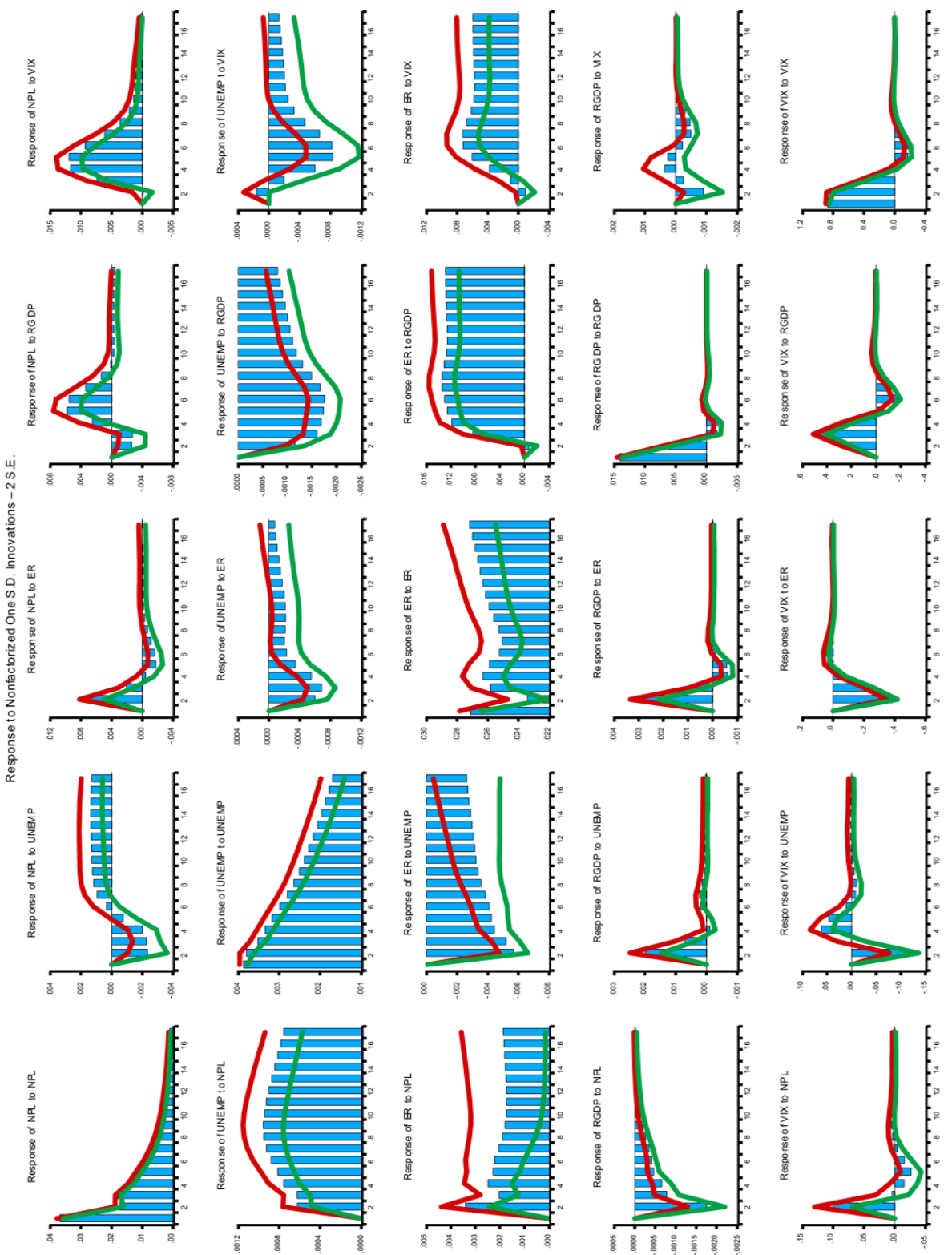

Figure 3. Impulse Response Function (macroeconomic variables)

Errors are $5 \%$ on each side generated by Monte-Carlo with 300 reps. *Shocks are on one standard deviation 

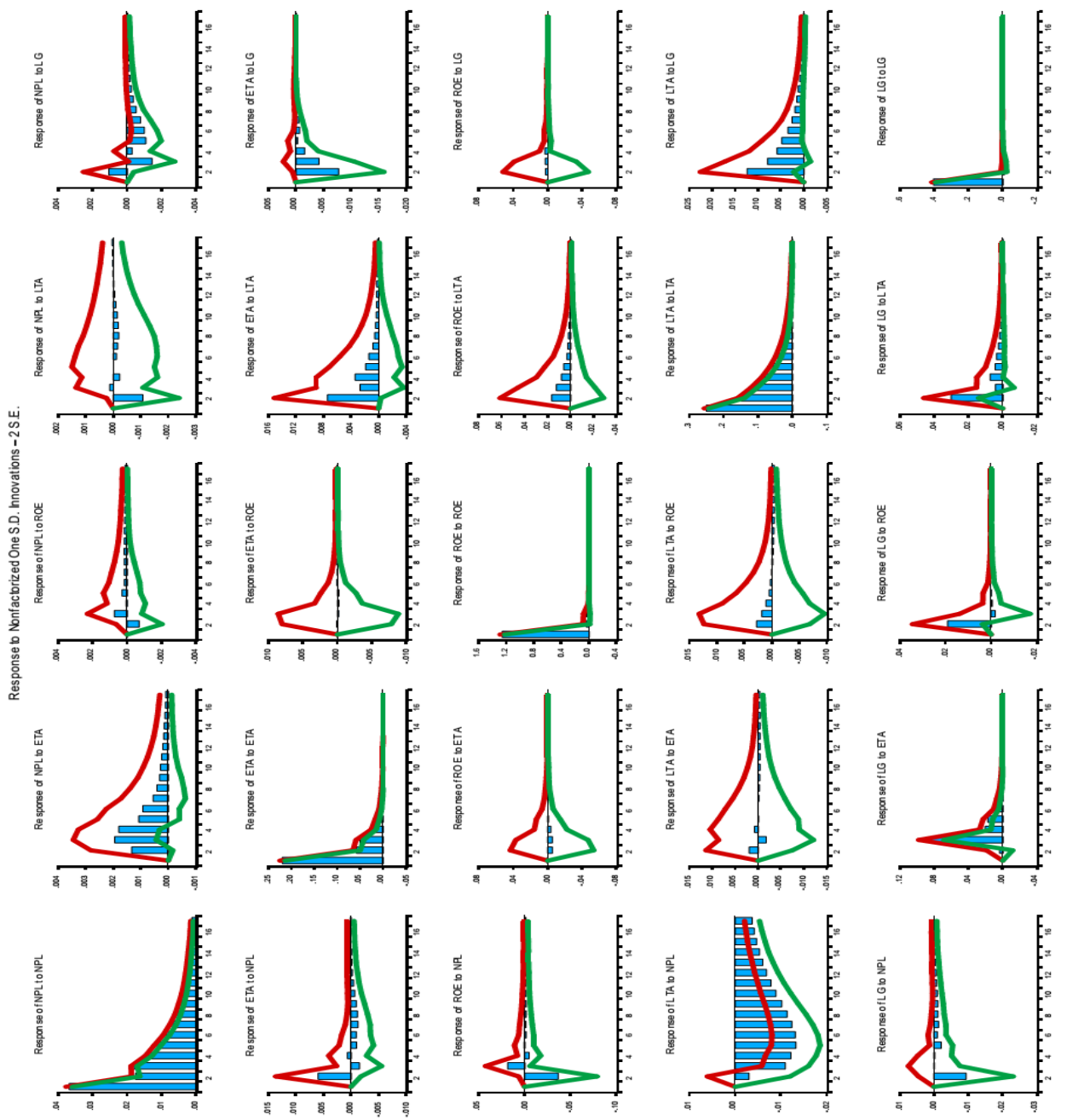

Figure 4. Impulse Response Function (microeconomic variables)

* Errors are $5 \%$ on each side generated by Monte-Carlo with 300 reps.

*Shocks are on one standard deviation

\subsection{Variance decomposition}

Variance decomposition postulates the degree to which a variable's forecasted error is related with exogenous shocks to rest of the endogenous variable. The technique exposes $N P L$ is playing a vital role in affecting the economic variable during the 6-year period horizon. In Table 13A, VIX is the most information about 
NPLs variation and then similarly significant are ER and RGDP. In Table 13B, NPL variation is more significant by $L G$ and then equally important are $R O E$ and $L T A$. In Table 13A and Table 13B, the explanatory power of NPL regarding the variation of endogenous variable is more than the explanatory power of endogenous variables to the variation of NPL.

\section{Table 13A. Variance Decomposition (macroeconomic variables)}

\begin{tabular}{cccccccc}
\hline & Horizon & $\mathrm{NPL}(1)$ & Unempl(2) & $\operatorname{Inf}(3)$ & $\mathrm{ER}(4)$ & $\mathrm{RGDP}(5)$ & $\mathrm{VIX}(6)$ \\
\hline$(1)$ & 6 & 0.034336 & 0.004835 & -0.002647 & 0.001827 & -0.004182 & 0.003735 \\
$(2)$ & 6 & 0.052623 & 0.005754 & -0.009861 & 0.009436 & -0.011309 & 0.009859 \\
$(3)$ & 6 & 0.070186 & 0.006731 & -0.003493 & 0.014461 & -0.023273 & 0.022358 \\
$(4)$ & 6 & 0.084674 & 0.005990 & 0.000619 & 0.020204 & -0.030592 & 0.033709 \\
$(5)$ & 6 & 0.095897 & 0.004974 & 0.003751 & 0.021993 & -0.033041 & 0.041433 \\
$(6)$ & 6 & 0.104575 & 0.005191 & 0.007071 & 0.023320 & -0.033716 & 0.047129 \\
\hline
\end{tabular}

Table 13B. Variance Decomposition (microeconomic variables)

\begin{tabular}{ccccccc}
\hline & Horizon & $\mathrm{NPL}(1)$ & $\mathrm{ETA}(2)$ & $\mathrm{ROE}(3)$ & $\mathrm{LTA}(4)$ & $\mathrm{LG}(5)$ \\
\hline$(1)$ & 5 & 0.039380 & 0.001040 & -0.000609 & -0.001098 & -0.002539 \\
$(2)$ & 5 & 0.061031 & 0.002417 & -0.001675 & -0.002467 & -0.003601 \\
$(3)$ & 5 & 0.081115 & 0.004886 & -0.001270 & -0.002860 & -0.007261 \\
$(4)$ & 5 & 0.096621 & 0.007191 & -0.001365 & -0.002980 & -0.009427 \\
$(5)$ & 5 & 0.109166 & 0.008828 & -0.001284 & -0.002805 & -0.011249 \\
\hline
\end{tabular}

Note: \% of variation in the row variable explained by the column variables

\subsection{Generalized method of moment (GMM)}

Table 13 mostly approve the impact of NPL on macroeconomic indicators and bankspecific variables. However, the bank-specific variables response toward NPL is relatively less due to their indulgence, which marginally surge the within explanatory influence of every group while diminishes the between influence in the fixed effect estimations. The Sargan test clarify that instruments are uncorrelated with the residuals. The Arellano Bond test accept the alternative hypothesis that the errors are auto correlated at $A R(1)$ and $A R(2)$. Furthermore, NPL were found to have low auto correlated, which means the coefficients size of lag NPL ranges between $0.6403-0.6438$. This phenomenon proposing that NPL shock has a short term impact on banking system.

\subsubsection{Macroeconomic indicators}

The empirical findings contended (Table 14A, 14B, 14C) that augmenting the unemployment level can surge the NPL authenticating the correlation between banking system flexibility and business cycle. Inflation results are congruent with economic theory at fixed effect (which is boosting up the inflation will increase the NPL level), but contrasting at difference and system GMM. Exchange rate appreciation is also exposes adverse results with NPL. Lower South Asian RGDP reduces the firm capacity to repay loan to bank which is confirming the economic theory which is adverse in VIX. 
Determinants of Non-Performing Loan in South Asia: The Role of Financial Crisis

Table 14A Regression results by GMM (1999-2007, pre-crisis period)

\begin{tabular}{lllllll}
\hline \multicolumn{2}{c}{ Fixed Effect } & \multicolumn{2}{c}{ Difference GMM } & \multicolumn{2}{c}{ System GMM } \\
\hline NPL(-1) & $0.8028^{* * *}$ & $0.6809^{* * *}$ & $0.6973^{* * *}$ & $0.5548^{* * *}$ & $0.7488^{* * *}$ & $0.6631^{* * *}$ \\
Macroeconomic Variables & & & & & \\
Unemp(-1) & $-0.495^{* * *}$ & $-0.755^{* * *}$ & $-0.926^{* * *}$ & $-1.118^{* * *}$ & $0.06714^{* *}$ & 0.035791 \\
Inf(-1) & -0.030339 & 0.000273 & $-0.034^{* * *}$ & $0.035927^{*}$ & $-0.063^{* * *}$ & $-0.043^{* * *}$ \\
D_Ex_Rate & -0.059598 & $-0.308^{* * *}$ & $-0.295^{* * *}$ & $-0.427^{* * *}$ & 0.0311939 & $-0.102^{* * *}$ \\
RGDP_ASIA & $-1.041^{* * *}$ & $-1.809^{* * *}$ & $-0.624^{* * *}$ & $-1.063^{* * *}$ & $-1.040^{* * *}$ & $-1.559^{* * *}$ \\
VIX & $-0.009^{* * *}$ & $-0.026^{* * *}$ & $-0.009^{* * *}$ & $-0.019^{* * *}$ & $-0.0065^{* *}$ & $-0.019^{* * *}$ \\
Bank-Level Variables & & & & & & \\
Equity-to-Assets(-1) & & 0.009579 & & 0.0212052 & & $0.015857^{*}$ \\
ROE(-1) & & -0.000544 & & $-0.0006^{* *}$ & & $-0.0006^{* *}$ \\
Loan-to-Assets(-3) & & -0.000955 & & 0.0026449 & & -0.004187 \\
Loans-Growth & & -0.001773 & & -0.002294 & & -0.002809 \\
C & $0.0980^{* * *}$ & $0.1676^{* * *}$ & $-0.007^{* * *}$ & $-0.009^{* * *}$ & $0.0777^{* * *}$ & $0.1170^{* * *}$ \\
\hline Country Dummies & No & No & No & No & Yes & Yes \\
No. of Obs. & 1560 & 1170 & 1365 & 975 & 1560 & 1170 \\
R2 & 0.915928 & 0.871615 & & & & \\
No. of Banks & 195 & 195 & 195 & 195 & 195 & 195 \\
No. of Instruments & 202 & 206 & 33 & 36 & 40 & 42 \\
Sargan Test & & & $1346.9 * *$ & $991.39^{* * *}$ & $3369.9 * * *$ & $2535.9^{* * *}$ \\
A-B AR(1) test & & & $-9.6149^{* * *}$ & $-8.4482^{* * *}$ & $-8.1606^{* * *}$ & $-7.2255^{* * *}$ \\
A-B AR(2) test & & & $-6.3372^{* * *}$ & $-5.6572^{* * *}$ & $-3.0835^{* * *}$ & $-3.0911^{* * *}$ \\
\hline
\end{tabular}

Table 14B. Regression results by GMM (2008-2015, post-crisis period)

\begin{tabular}{lllllll}
\hline & \multicolumn{2}{c}{ Fixed Effect } & \multicolumn{2}{c}{ Difference GMM } & \multicolumn{2}{c}{ System GMM } \\
\hline NPL(-1) & -0.032810 & $0.03264^{* *}$ & -0.072224 & 0.0010879 & $0.0566^{* * *}$ & $0.02941^{* *}$ \\
Macroeconomic Variables & & & & & \\
Unemp(-1) & $-3.978^{* * *}$ & $-0.762^{* * *}$ & $-5.872^{* * *}$ & $-0.8174^{* *}$ & $1.3323^{* * *}$ & $1.3758^{* * *}$ \\
Inf(-1) & $-0.335^{* * *}$ & $0.2665^{* * *}$ & $-0.539^{* * *}$ & $0.3043^{* * *}$ & $-0.213^{* * *}$ & $0.6128^{* * *}$ \\
D_Ex_Rate & $-0.197^{* * *}$ & $-0.236^{* * *}$ & $0.09748^{* *}$ & $-0.164^{* * *}$ & 0.0221899 & $-0.303^{* * *}$ \\
RGDP_ASIA & $0.5176^{* * *}$ & $0.5777^{* * *}$ & $0.8058^{* * *}$ & -0.108814 & $0.4750^{* * *}$ & $1.1674^{* * *}$ \\
VIX & $-0.003^{* * *}$ & $0.001310^{*}$ & $-0.011^{* * *}$ & $0.0040^{* * *}$ & $-0.007^{* * *}$ & $0.0025^{* * *}$ \\
Bank-Level Variables & & & & & & \\
Equity-to-Assets(-1) & & 0.001041 & & 0.0003694 & & $0.0054^{* * *}$ \\
ROE(-1) & & -0.001414 & & -0.002637 & & $-0.0033^{* *}$ \\
Loan-to-Assets(-3) & & 0.002313 & & $0.002536^{*}$ & & $-0.0093^{* *}$ \\
Loans-Growth & & $-0.003^{* * *}$ & & $-0.004^{* * *}$ & & $-0.004^{* * *}$ \\
C & $0.2388^{* * *}$ & $0.0452^{* * *}$ & $-0.006^{* * *}$ & $0.0041^{* * *}$ & $-0.01345^{*}$ & $-0.105^{* * *}$ \\
\hline Country Dummies & No & No & No & No & Yes & Yes \\
No. of Obs. & 1365 & 975 & 1170 & 780 & 1365 & 975 \\
R2 & 0.669302 & 0.888056 & & & & \\
No. of Banks & 195 & 195 & 195 & 195 & 195 & 195 \\
No. of Instruments & 202 & 206 & 27 & 30 & 33 & 35 \\
Sargan Test & & & $337.89 * * *$ & $745.83^{* * *}$ & $458.91^{* * *}$ & $671.49 * * *$ \\
A-B AR(1) test & & & $-7.0209 * * *$ & -1.40993 & NA & $-5.9646^{* * *}$ \\
A-B AR(2) test & & & $2.9422^{* * *}$ & $4.7545^{* * *}$ & NA & $4.5892^{* * *}$ \\
\hline
\end{tabular}


Table 14C. Regression results by GMM (Overall)

\begin{tabular}{lllllll}
\hline \multicolumn{2}{c}{ Fixed Effect } & \multicolumn{2}{c}{ Difference GMM } & \multicolumn{2}{c}{ System GMM } \\
\hline NPL(-1) & $0.6438^{* * *}$ & $0.6295^{* * *}$ & $0.5956^{* * *}$ & $0.5072^{* * *}$ & $0.6403^{* * *}$ & $0.5297^{* * *}$ \\
Macroeconomic Variables & & & & & \\
Unemp(-1) & $1.0900^{* * *}$ & $0.9198^{* * *}$ & $-0.7769^{* * *}$ & $-0.7721^{* * *}$ & $0.1468^{* * *}$ & $0.1953^{* * *}$ \\
Inf(-1) & $0.0386^{* * *}$ & $0.0512^{* * *}$ & $-0.1412^{* * *}$ & $-0.1177^{* *}$ & $-0.1385^{* *}$ & $-0.1272^{* *}$ \\
D_Ex_Rate & $-0.0957^{* * *}$ & $-0.1062^{* * *}$ & $-0.1009^{* * *}$ & $-0.1129^{* * *}$ & $-0.1026^{* * *}$ & $-0.1331^{* * *}$ \\
RGDP_ASIA & $-0.3715^{* * *}$ & $-0.3490^{* * *}$ & $-0.6060^{* * *}$ & $-0.4687^{* * *}$ & $-0.5563^{* * *}$ & $-0.4312^{* * *}$ \\
VIX & -0.0003 & $-8.74 \mathrm{E}^{-05}$ & $-0.0042^{* * *}$ & $-0.0053^{* * *}$ & $-0.0018^{* *}$ & $-0.0032^{* * *}$ \\
Bank-Level Variables & & & & & & \\
Equity-to-Assets(-1) & & 0.004387 & & -0.000177 & & 0.005119 \\
ROE(-1) & & -0.000999 & & $-0.0010^{* * *}$ & & $-0.0006^{* * *}$ \\
Loan-to-Assets(-3) & & $-0.006671^{*}$ & & $0.00895^{* *}$ & & 0.0002742 \\
Loans-Growth & & $-0.0077^{* * *}$ & & $-0.00947^{* *}$ & & $-0.0085^{* *}$ \\
C & $0.0559^{* * *}$ & $0.0611^{* * *}$ & $-0.0015^{* * *}$ & $-0.0015^{* * *}$ & $0.0659^{* * *}$ & $0.0618^{* * *}$ \\
\hline Country Dummies & No & No & No & No & Yes & Yes \\
No. of Obs. & 2730 & 2535 & 2925 & 2535 & 3120 & 2730 \\
R2 & 0.763511 & 0.763369 & & & & \\
No. of Banks & 195 & 195 & 195 & 195 & 195 & 195 \\
No. of Instruments & 205 & 221 & 92 & 93 & 107 & 107 \\
Sargan Test & & & $1797.5^{* * *}$ & $1580.8^{* * *}$ & $4791.8^{* * *}$ & 3680.29 \\
A-B AR(1) test & & & $-4.6972^{* * *}$ & $-4.9393^{* * *}$ & $-4.5471^{* * *}$ & -4.8237 \\
A-B AR(2) test & & & $4.7851^{* * *}$ & $5.2532^{* * *}$ & $4.6041^{* * *}$ & 5.0075 \\
\hline
\end{tabular}

Note: ${ }^{1}$ An increase in exchange rate designates depreciation

\subsubsection{Bank-specific factors}

The results exposes that equity to asset ratio has no impact on NPL in the South Asian region. The bank profitability is adversely correlated with NPL proposing that improved bank management has an average better quality of assets (validating the bad-management theory). Unnecessary advancing (measured by LTA) results in appreciating NPL at difference GMM. To grasp the past unnecessary advancing, lagged lending growth (LG) is used which yielding higher NPL. Other variables like bank size and revenue growth in other studies are proved insignificant with NPL in case of South Asian region.

\subsubsection{Robustness}

To grasp the robustness of the outcomes specifically with the effect of financial crisis, the study data is distributed in two sub samples - pre crisis stage (19992007) and post crisis stage (2008-2015). Table $12 \mathrm{~A}$ and Table $12 \mathrm{~B}$ point out that $\Delta$ unemployment and inflation has more impact in post-crisis period than pre-crisis period. Exchange Rate, RGDP and VIX are seems to be more effective in the postcrisis period compare to pre-crisis period. In the bank-specific factors, ETA and ROE has prominent impact both in pre and post crisis period while rest of the variables is significant only in the post crisis period. Although significance of the bank-specific variable mainly relies on estimation technique. 


\section{Conclusion and Policy Implications}

Recently in the South Asian region, banks experienced a great loss in assets and capital buffers due to rapid increase in NPLs which consequently effecting the overall economic performance. The rapid surge in NPL does not only raise bank susceptibility to upcoming uncertainties, but also limiting their lending operations. This study attempts to identify the determinants of NPLs over-time and across South Asian region using variant panel econometric practices.

Although the study empirical results robust with alternative specifications, which means that macroeconomic variables and bank-specific variable are treated separately with NPL in order to gauge their isolated impact. Particularly the study confirms that NPL level augment when inflation is high, exchange rate depreciates and unemployment rises. The study also confirms that management quality of bank (measured by profitability) is inversely proportional to level of NPL. Furthermore, level of risk (calculated by bank loan growth rate and loan to asset ratio) is directly proportional to NPLs. Such bank specific factors are momentous in both periods (pre and post crisis).

The analysis of the study creates a major feedback by providing a link between banking system with economic performance across South Asian regions over a period of 1999-2015. It is found that NPLs are responding to some of the major macroeconomic factors like $R G D P$, inflation and unemployment. Therefore, the study suggest that prolong growth can be attained only by making an elastic and sound banking system.

Finally, the study conclusion has a few policy implications. In view of the NPL significant impact on macroeconomic indicators and bank-specific factors, the study suggests to put merit in loan supervision to prevent rapid surge in NPL in future. Such rationale includes introducing advance credit standards, avoiding banks excessive lending's, and restraining foreign currency lending to confront borrowers. Although the policy regarding NPL should be in a proactive approach. It means contamination of hidden taxes, removal of unnecessary regulation which directly or indirectly facilitates portfolio cleanup process and makes favors to both debtors and creditors in their financial operations.

\section{References}

Arellano, M. \& O. Bover. (1995). Another Look at the Instrumental-Variable Estimation of Error-Components. Journal of Econometrics, 68, 29-52. https://doi.org/10.1016/03044076(94)01642-D

Berger, A. \& R. DeYoung. (1997). Problem Loans and Cost Efficiency in Commercial Banks. Journal of Banking and Finance, 21, 849-870. https://doi.org/10.1016/S03784266(97)00003-4

Blundell, R., \& S. Bond. (1998). Initial conditions and moment restrictions in dynamic panel data models. Journal of Econometrics, 87, 115-143. https://doi.org/10.1016/S0304$\underline{4076(98) 00009-8}$ 


\section{Obaid Ur REHMAN}

Caselli S., Gatti S. \& Querci F. (2008). The sensitivity of the loss given default rate to systematic risk: New empirical evidence on bank loans. Journal of Financial Services Research 34, 1-34. https://doi.org/10.1007/s10693-008-0033-8

Durbin, J., \& Watson, G. S. (1951). Testing for serial correlation in least squares regression. II. Biometrika, 38(1-2), 159-178. https://doi.org/10.2307/2332325

Espinosa, R., \& A. Prasad. (2010). Nonperforming Loans in the GCC Banking Systems and their Macroeconomic Effects. IMF Working Paper 10/224 Washington: International Monetary Fund.

Fofack, H. (2005). Non-performing Loans in Sub-Saharan Africa: Causal Analysis and Macroeconomic Implications. World Bank Policy Research Working Paper, No. 3769. https://doi.org/10.1596/1813-9450-3769

Jimenez, G., \& J. Saurina. (2005). Credit cycles, credit risk, and prudential regulation. Banco de Espana, January.

Klein, N. (2013). Non-performing loans in CESEE: Determinants and impact on macroeconomic performance. IMF Working Paper, 13/72. https://doi.org/10.5089/9781484318522.001

Kmenta, J. (1986). Elements of Econometrics. New York: Macmillan

Keeton, W. R., \& Morris, C. S. (1987). Why do banks' loan losses differ? Economic ReviewFederal Reserve Bank of Kansas City, 72(5), 3.

Louzis, D. P., Vouldis, A. T., \& Metaxas, V. L. (2012). Macroeconomic and bank-specific determinants of non-performing loans in Greece: A comparative study of mortgage, business and consumer loan portfolios. Journal of Banking \& Finance, 36(4), 1012-1027. https://doi.org/10.1016/i.jbankfin.2011.10.012

Love, I. \& L. Zicchino. (2006). Financial Development and Dynamic Investment Behavior: evidence from Panel VAR. The Quarterly Review of Economics and Finance, 46, 190-210. https://doi.org/10.1016/j.qref.2005.11.007

Nkusu, M. (2011). Nonperforming loans and macro financial vulnerabilities in advanced economies. IMF Working Paper, 11/161. https://doi.org/10.5089/9781455297740.001

Odell, P. L. (1983). Gauss-Markov theorem. Encyclopedia of statistical sciences.

Parks, Richard W. (1967). Efficient estimation of a system of regression equations when disturbances are both serially and contemporaneously correlated. Journal of American Statistical Association 62, 500-509. https://doi.org/10.1080/01621459.1967.10482923

Podpiera, J. \& L. Weill. (2008). Bad Luck or Bad Management? Emerging Banking Market Experience. Journal of Financial Stability, 4(2), 135-148. https://doi.org/10.1016/i.jfs.2008.01.005

Rajan, R. \& S.C. Dahl. 2003. Non-performing Loans and Terms of Credit of Public Sector Banks in India: An Empirical Assessment. Occasional Papers, 24/3 Reserve Bank of India.

Reinhart, C. \& Rogoff, K. (2010). From Financial Crash to Debt Crisis. NBER Working Paper 15795. https://doi.org/10.3386/w15795

Salas, V. \& J. Saurina. (2002). Credit Risk in Two Institutional Regimes: Spanish Commercial and Savings Banks. Journal of Financial Services Research, 22(3), 203-224. https://doi.org/10.1023/A:1019781109676

Williams, J. (2004). Determining Management Behavior in European Banking. Journal of Banking and Finance, 28, 2427-2460. https://doi.org/10.1016/j.jbankfin.2003.09.010. 